\title{
EFFECTS OF HALOTHANE ANAESTHESIA AND SURGERY ON ADRENOCORTICAL FUNCTION IN MAN
}

\author{
Tsutomu Oxama, M.D., S. Shibata, M.D., F. Matusmoto, M.D., \\ M. TAKIGUChI, M.D., AND T. KUdo, B.S."
}

ThE PRESENT STUDY was undertaken to investigate the effects of halothane anaesthesia and surgery on adrenal cortical function by determining free 17-hydroxycorticosteroid (= 17-OHCS, hydrocortisone or cortisol) in the plasma of peripheral venous blood in man. Although other anaesthetic agents have been shown to have some influence on plasma free cortisol levels in man, ${ }^{1-3}$ information on the effect of halothane anaesthesia has been scant. Lewis ${ }^{4}$ reported a statistically insignificant rise of mean plasma cortisol levels in eight patients undergoing halothane anaesthesia.

\section{Patients}

\section{METHOD}

Thirty-one patients ranging from 16 to 66 years of age were studied. None had any clinical evidence of endocrine disorder or impaired renal or hepatic function, nor had any received ACTH or corticosteroid compounds. They were divided into three groups of ten or eleven patients each. The first group was induced with thiopental, and the second group directly with halothane, nitrous oxide, and oxygen.

The third group of eleven unoperated patients was studied to investigate the effects of the premedication alone on the adrenocortical function. The diagnosis and surgical procedures performed in the halothane anaesthesia groups are shown in Table I.

\section{Premedication}

Each patient was given pentobarbital $50 \mathrm{mg}$. or $100 \mathrm{mg}$. orally $1 \frac{1}{2}$ hours before the induction of anaesthesia. Atropine $0.5 \mathrm{mg}$. and meperidine $35 \mathrm{mg}$. were given by intramuscular injection $1_{14}^{1 /}$ hours prior to induction.

\section{Anaesthetic Technique}

Because of the diurnal variations of the concentration of 17-OHCS in the plasma in man, we started all anaesthetic inductions between 8:15 and 8:45 A.M. The ten patients of the first group were induced by injection of 2.5 per cent solution of thiopental sodium (187-250 mg.), followed with succinylcholine chloride (S.C.C.) $40 \mathrm{mg}$. for endotracheal intubation. The ten patients in the second group were induced with halothane, nitrous oxide, and oxygen under a mask, insead of with thiopental.

'Department of Anaesthesia, Hirosaki University School of Medicine, Hirosaki, Japan. Dr. Oyama is Professor of the Department. 
TABLE I

Patients and Operations

\begin{tabular}{rllll}
\hline \hline $\begin{array}{c}\text { Case } \\
\text { no. }\end{array}$ & Patient & Age & Sex & \multicolumn{1}{c}{ Operation } \\
\hline & & & & \\
1 & G.N. & 66 & $\mathrm{M}$ & esophagotomy \\
2 & H.I. & 39 & $\mathrm{~F}$ & laparotomy \\
3 & K.O. & 41 & $\mathrm{M}$ & subtotal gastrectomy \\
4 & T.S. & 18 & $\mathrm{~F}$ & oophorectomy \\
5 & H.A. & 49 & $\mathrm{M}$ & subtotal gastrectomy \\
6 & S.T. & 37 & $\mathrm{~F}$ & sympathectomy \\
7 & Y.T. & 31 & $\mathrm{M}$ & extirpation of lymph nodes \\
8 & T.T. & 65 & $\mathrm{M}$ & subtotal gastrectomy \\
9 & M.K. & 49 & $\mathrm{~F}$ & fundectomy \\
10 & Y.M. & 36 & $\mathrm{M}$ & exploratory laparotomy \\
11 & F.A. & 45 & $\mathrm{~F}$ & gastrojejunostomy \\
12 & K.I. & 16 & $\mathrm{~F}$ & shelb-reduction \\
13 & Y.I. & 16 & $\mathrm{~F}$ & appendectomy \\
14 & K.K. & 35 & $\mathrm{~F}$ & amputation of rectum \\
15 & E.A. & 52 & $\mathrm{M}$ & hemithyroidectomy \\
16 & M.F. & 40 & $\mathrm{M}$ & extirpation of tumour \\
17 & S.K. & 20 & $\mathrm{M}$ & extirpation of tumour \\
18 & K.E. & 55 & $\mathrm{M}$ & subtotal gastrectomy \\
19 & T.K. & 35 & $\mathrm{~F}$ & curettage of region \\
20 & T.S. & 28 & $\mathrm{M}$ & subtotal gastrectomy \\
\hline
\end{tabular}

After endotracheal intubation, anaesthesia was maintained in both groups with nitrous oxide $2 \mathrm{~L}$./min., oxygen $2 \mathrm{~L} . / \mathrm{min}$. and halothane 0.5 to 1.5 per cent. Intermittent doses of $20 \mathrm{mg}$. of succinylcholine were given intravenously during anaesthesia to provide adequate relaxation of the abdominal muscles during surgery. Ventilation was controlled or assisted throughout the procedure. The average operating time was two hours ( $45 \mathrm{~min}$. to three hours $40 \mathrm{~min}$.). A moderate depth of anaesthesia was maintained during each procedure by clinical judgment based on observations of blood pressure, pulse rate, and somatic reflexes in response to the stimuli provided by the endotracheal tube or surgery.

\section{Determination of Free 17-OHCS Concentrations in the Plasma}

The blood sampling time was as follows: (1) the day before surgery at 3-5 P.M., (2) immediately before induction of anaesthesia, (3) 15 minutes after induction of anaesthesia (first group), (4) 30 minutes after induction of anaesthesia (second group), (5) immediately prior to the commencement of surgery ( second group), (6) immediately after the start of surgery (first group), (7) one to two hours after start of surgery, (8) in the recovery room.

Twelve ml. of venous blood was collected on each occasion in a heparinized syringe, rapidly transferred to a tube, and centrifuged within 30 minutes of collection. These plasma samples were kept at $-20^{\circ} \mathrm{C}$. prior to analysis. Five ml. of plasma was used for spectrophotometric determination by Peterson's modification $^{6}$ of the Porter-Silber method. ${ }^{5}$ Two determinations were made in each plasma sample and the mean value was taken. The duplicate error was $0.87 \mu \mathrm{g}$. per $100 \mathrm{ml}$. of plasma. 


\section{Results}

\section{Preanaesthetic Levels}

The mean preanaesthetic plasma level of 17-OHCS in the morning was $10.1 \pm$ $1.2 \mu \mathrm{g}$. per $100 \mathrm{ml}$. for the first group and $10.8 \pm 1.4 \mu \mathrm{g}$. per $100 \mathrm{ml}$. ( $\pm=$ standard error) for the second group, as illustrated in the Tables II and III. These values were lower than our normal range (14-18 $\mu \mathrm{g}$.) at 8:30 A.M. in this laboratory.

\section{TABLE II}

Free Plasma 17-OHCS Levels ( $\mu \mathrm{g} . / 100 \mathrm{~m}$ l.) During Halothane Anaesthesia and SURGERY

First Group: Thiopental-Halothane- $\mathrm{N}_{2} \mathrm{O}$

\begin{tabular}{crrrrrr}
\hline $\begin{array}{c}\text { Case } \\
\text { no. }\end{array}$ & $\begin{array}{c}\text { Pre- } \\
\text { premed. }\end{array}$ & Preinduc. & $\begin{array}{c}15 \text { min. } \\
\text { postinduc. }\end{array}$ & $\begin{array}{c}\text { Immed. } \\
\text { op. }\end{array}$ & $\begin{array}{c}\text { Op. } \\
1 \text { hr. }\end{array}$ & $\begin{array}{c}\text { Op. } \\
2 \mathrm{hr} .\end{array}$ \\
\hline 1 & 7.5 & 12.4 & 15.0 & 12.4 & 20.6 & 22.5 \\
2 & 9.3 & 7.5 & 22.8 & 25.0 & 30.6 & 32.4 \\
3 & 9.7 & 12.6 & 9.7 & 14.8 & 29.2 & - \\
4 & 12.7 & 13.2 & 14.6 & 28.0 & 33.8 & - \\
5 & 13.5 & 16.6 & 13.5 & 28.0 & 29.2 & 36.6 \\
6 & 8.3 & 8.8 & 7.3 & 8.1 & 10.2 & 15.1 \\
7 & 7.2 & 2.7 & 7.6 & 4.1 & 26.1 & - \\
8 & 10.4 & 8.4 & 7.6 & 20.6 & 30.4 & 19.2 \\
9 & 13.8 & 12.0 & 13.2 & 27.2 & 28.0 & 33.0 \\
10 & 8.0 & 7.2 & 8.0 & 5.7 & 39.6 & - \\
& & & & & & \\
mean & 10.1 & 10.1 & 11.9 & 17.4 & 27.8 & 26.4 \\
S.E. & \pm 0.7 & \pm 1.2 & \pm 1.5 & \pm 2.9 & \pm 2.4 & \pm 3.2 \\
$i$ & & & 1.053 & 3.050 & 6.341 & 5.139 \\
$p$ & & & N.S. & $0.02^{*}$ & $0.001^{*}$ & $0.01^{*}$ \\
\hline
\end{tabular}

*Statistically significant compared with preinduction values.

TABLE III

Free Plasma 17-OHCS Levels ( $\mu \mathrm{g} . / 100 \mathrm{ml}$.) During Halothane ANAESThesia and SURGery

Second Group: Halothane- $\mathrm{N}_{2} \mathrm{O}$

\begin{tabular}{lrccccc}
\hline $\begin{array}{l}\text { Case } \\
\text { no. }\end{array}$ & $\begin{array}{c}\text { Pre- } \\
\text { premed. }\end{array}$ & Preinduc. & $\begin{array}{c}30 \text { min. } \\
\text { postinduc. }\end{array}$ & $\begin{array}{c}\text { Op. } \\
1 \mathrm{hr} .\end{array}$ & $\begin{array}{c}\text { Op. } \\
2 \mathrm{hr} .\end{array}$ & $\begin{array}{c}\text { Rec. } \\
\text { rm. }\end{array}$ \\
\hline 11 & 10.3 & 10.1 & 14.3 & 24.6 & - & 35.0 \\
12 & 6.5 & 5.7 & 19.6 & 29.0 & 33.5 & 31.2 \\
13 & 12.6 & 16.3 & 30.0 & 34.8 & - & 43.9 \\
14 & 17.2 & 20.0 & 20.7 & 34.0 & 36.6 & 43.2 \\
15 & 4.8 & 9.1 & 13.4 & 25.2 & - & 22.8 \\
16 & 4.7 & 5.1 & 14.3 & 30.9 & -1.5 & 30.0 \\
17 & 9.0 & 9.2 & 11.0 & 22.6 & 29.5 & 24.4 \\
18 & 13.9 & 12.2 & 19.0 & 25.2 & 31.6 & 32.2 \\
19 & 8.9 & 10.9 & 16.3 & 16.9 & 21.4 & 26.5 \\
20 & 7.2 & 8.9 & 16.8 & 20.0 & 37.7 & 37.6 \\
& 9.5 & 10.8 & 17.5 & 26.3 & 31.7 & 32.7 \\
mean & \pm 1.2 & \pm 1.4 & \pm 1.6 & \pm 1.8 & \pm 2.2 & \pm 2.2 \\
S.E. & & & 4.782 & 8.531 & 7.268 & 12.676 \\
$p$ & & & $0.001^{*}$ & $0.001^{*}$ & $0.001^{*}$ & $0.001^{*}$ \\
\hline
\end{tabular}

*Statistically significant compared with preinduction values. 
Analysing the data of the third group of patients who received premedication alone (Table IV), we found that the plasma level of free 17-OHCS at 8.30 A.M. before premedication was $18.20 \pm 1.58 \mu \mathrm{g}$. per $100 \mathrm{ml}$, and it was remarkably decreased to $13.98 \pm 1.21 \mu \mathrm{g}$. per $100 \mathrm{ml}$. on the following day when the premedication was administered. The difference between these figures is statistically significant $(t=4.42, p<0.005)$.

\section{TABLE IV}

Effect of Premedication on Plasma Free 17-OHCS Levels ( $\mu \mathrm{g} . / 100 \mathrm{ml}$.) at 8:30 A.M.

\begin{tabular}{ccc}
\hline $\begin{array}{c}\text { Case } \\
\text { no. }\end{array}$ & Control & Premedication \\
\hline 1 & 18.3 & 12.0 \\
2 & 21.6 & 14.0 \\
3 & 38.0 & 17.1 \\
4 & 17.0 & 12.5 \\
5 & 15.1 & 10.7 \\
6 & 19.0 & 17.8 \\
7 & 16.7 & 16.0 \\
8 & 11.9 & 9.3 \\
9 & 8.3 & 7.5 \\
10 & 20.0 & 14.8 \\
11 & 24.4 & 22.1 \\
mean & 18.20 & 13.98 \\
S.E. & \pm 1.58 & \pm 1.21 \\
\hline
\end{tabular}

$t=4.42, p<0.005$.

\section{Effects of Halothane Anaesthesia}

In the ten patients in whom anaesthesia was induced with thiopental (first group), the mean presurgical concentration after 15 minutes of halothane anaesthesia was increased by $1.8 \mu \mathrm{g}$. per $100 \mathrm{ml}$. of plasma above the preanaesthetic level (Fig. 1). This increase is not statistically significant.

In the ten patients in whom halothane anaesthesia was administered for 30 minutes without using thiopental (second group), the mean preanaesthetic plasma level of free $17-\mathrm{OHCS}$ rose significantly by $6.7 \mu \mathrm{g}$. per $100 \mathrm{ml}$. $(t=4.78$, $p<0.001$ ) above the morning preanaesthetic level (Fig. 2).

\section{Plasma Levels during Operation}

The mean plasma level of free 17-OHCS in the ten patients immediately after starting surgery was $17.4 \mu \mathrm{g}$. per $100 \mathrm{ml}$., an increase of $7.3 \mu \mathrm{g}$. per $100 \mathrm{ml}$. of plasma above the preanaesthetic level. This is a statistically significant difference $(t=3.05, p<0.02)$.

The mean plasma 17-OHCS concentration at one hour after starting surgery was $27.8 \pm 2.4 \mu \mathrm{g}$. per $100 \mathrm{ml}$. in the first group and $26.3 \pm 1.8 \mu \mathrm{g}$. per $100 \mathrm{ml}$. in the second group. Further remarkable elevation of the 17-OHCS in plasma was noted at the two-hour interval after starting surgery as illustrated in Tables II and III. These increases above the preanaesthetic concentrations represent a statistically significant difference $(p<0.001)$. 


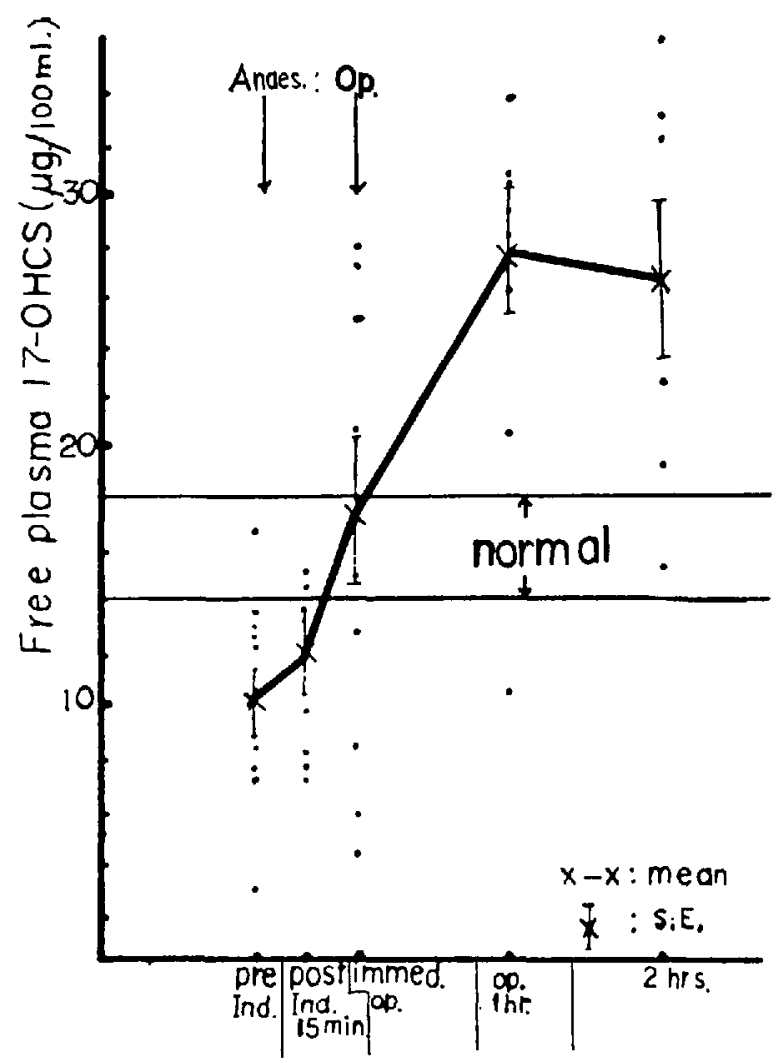

FIGURE 1. Effects of halothane- $\mathrm{N}_{2} \mathrm{O}$ anaesthesia (induced with thiopental) on plasma free 17-OHCS concentrations in man (first group). In our laboratory normal mean plasma 17-OHCS levels were $18 \mu \mathrm{g}$, at 8:30 A.M. and $14 \mu \mathrm{g}$. at 12:30 A.M.

\section{Postsurgical Level}

Postsurgical levels in the recovery room, when the patients were considered to have fully recovered from anaesthesia, were still high, and were recorded as $32.7 \mu \mathrm{g}$. per $100 \mathrm{ml}$. of plasma $(t=12.6, p<0.001)$.

\section{Discussion}

The mean plasma level of free 17-OHCS between 8:15 and 8:45 A.M. after preanaesthetic medication with pentobarbital, meperidine, and atropine was 10.1-10.8 $\mu \mathrm{g}$. per $100 \mathrm{ml}$. This value was lower than the normal limit in our laboratory (14-18 $\mu \mathrm{g}$.) in the morning at 8:30 A.M. The mean plasma level of free 17-OHCS in 11 non-premedicated patients between 8:15 and 8:45 A.M. was $18.20 \pm 1.58 \mu \mathrm{g}$, and their levels were significantly decreased to $13.98 \pm 1.21 \mu \mathrm{g}$. when premedication was given $(t=4.42, p<0.005)$.

Our demonstration of decrease in plasma level of free 17-OHCS by premedication accords with other reports such as those of Siker (by pentobarbital) and 


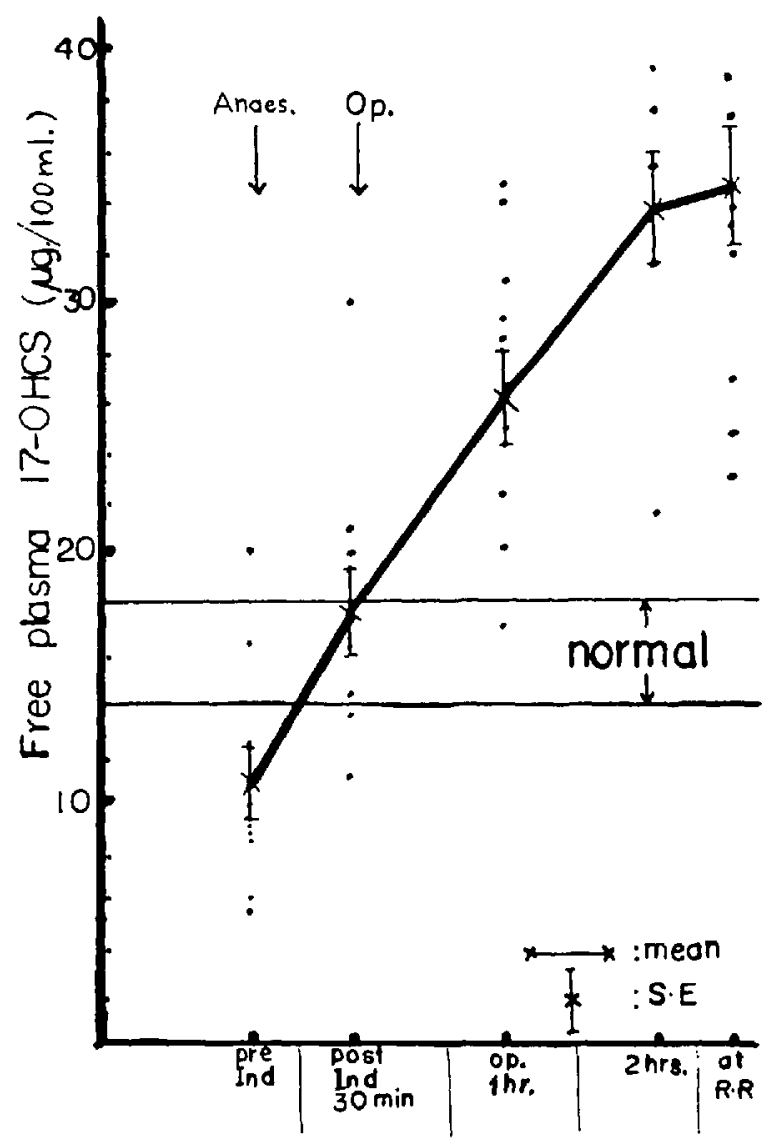

FIGURE 2. Effects of halothane- $\mathrm{N}_{2} \mathrm{O}$ anaesthesia (without thiopental) on plasma free 17-OHCS concentrations in man (second group).

$\mathrm{Han}^{8}$ (by meperidine) who observed decrease of plasma levels of free 17-OHCS in man. However, our data differ from those given in other reports such as those of Virtue et al., ${ }^{2}$ Hammond et al., ${ }^{1}$ and Vandam and Moore, ${ }^{3}$ who did not observe a significant decrease of plasma 17-OHCS by preanaesthetic medication. The discrepancy between our data and those given in other reports would seem to result mainly from the fact that those studies did not compare values for premedicated patients with those for the same subjects without premedication at a similar time in the morning. Therefore they failed to consider the diurnal variation of plasma levels of free $17-\mathrm{OHCS},{ }^{8,10}$ and their data were within normal limits in comparison with the variation of resting level which ranged from 5 to $18 \mu \mathrm{g}$. in a day.

Franksson et al. ${ }^{11}$ showed significantly increased plasma 17-OHCS levels in 33 surgical patients in the preoperative period between 7 and 8 A.M. The average plasma level of 17-OHCS on the day of operation was reported by them as $14.51 \mu \mathrm{g}$., while the level two days before the operation was $5.53 \mu \mathrm{g}$., and one 
day before, $8.55 \mu \mathrm{g}$. They postulated that it is the emotional state which causes the observed stimulation of the adrenal cortex.

Although mean elevations of free 17-OHCS concentration in plasma were small and statistically insignificant after 15 minutes of halothane anaesthesia, the patients who were anaesthetized for 30 minutes by halothane did show a statistically significant rise of plasma 17-OHCS concentrations.

Stark ${ }^{12}$ reported an increase in 24-hour urinary cortisol and cortisone secretion after halothane anaesthesia and surgery. It is impossible to separate the effect of halothane anaesthesia alone from his data. Lewis ${ }^{4}$ observed a slight but insignificant rise of free hydrocortisone concentrations in eight patients who were induced with thiopentone and maintained using halothane and oxygen with d-tubocurarine. The mean preinduction level was $12.2 \pm 2.0 \mu \mathrm{g}$. ( $\pm=$ standard error) and it rose to a presurgical level of $13.7 \pm 2.2 \mu \mathrm{g}$. per $100 \mathrm{ml}$.

Factors which control the concentration of free 17-OHCS in peripheral blood are (1) the rate of secretion of $17-\mathrm{OHCS}$ into the blood by the adrenal cortex, (2) the rate of removal of 17-OHCS from the blood as a result of metabolism by the liver and utilization by the tissues. Hume and Bell ${ }^{13}$ clearly demonstrated the increase of 17-OHCS concentrations in the adrenal venous blood in man associated with ether anaesthesia. One of the present authors and colleagues demonstrated that the rise of plasma ACTH concentration accounts for the increased free 17-OHCS levels in plasma during ether anaesthesia in man. ${ }^{14}$

One cannot neglect the factor of impaired renal and hepatic function during anaesthesia and surgery. It is well documented that the cortisol metabolism in the liver is handled in a quite different manner under stress than it is in the resting state. $^{15,16}$ The impaired conjugation of cortisol in the liver could account for the high plasma level of cortisol in the peripheral blood. However, Estep et al. ${ }^{17}$ recently demonstrated that under surgical stress the hepatic factor for plasma 17-OHCS levels in healthy man is not a main role.

\section{SUMMARY AND CONCLUSIONS}

The present study was undertaken to investigate whether or not preanaesthetic medication and halothane anaesthesia affect adrenal cortical function in man as judged by their influence on the plasma levels of free 17-hydroxycorticosteroids. The blood samples were taken in the morning between $8: 15$ and 8.45 A.M. before induction of anaesthesia, during anaesthesia alone, during surgery, and in the recovery room. The determination of free 17-OHCS in plasma was made by Peterson's modification of the Porter-Silber method. Twenty patients were given halothane anaesthesia and another eleven patients received premedication alone without anaesthesia.

The mean plasma level of 17-OHCS in the preanaesthetic period was in the range of $10.0-10.8 \mu \mathrm{g}$. per $100 \mathrm{ml}$., which was significantly lower than for the non-premedicated patients. Although halothane anaesthesia for 15 minutes after induction with thiopental evoked slight but insignificant increase of 17-OHCS level, halothane anaesthesia for 30 minutes without employing thiopental significantly increased the plasma 17-OHCS levels above the preinduction levels, from 
$10.8 \pm 1.4$ to $17.5 \pm 1.6 \mu \mathrm{g}$. ( $\pm=$ standard error) per $100 \mathrm{ml}$. The surgical stress increased plasma 17-OHCS levels markedly. These findings indicate that halothane anaesthesia has a stimulating effect on adrenal cortical function in man.

\section{RÉSUMÉ}

Le présent travail a été entrepris pour chercher si oui ou non la prémédication et l'anesthésie à l'halothane affectent la fonction du cortex surrénalien chez l'homme, autant qu'on peut en juger par leur influence sur les niveaux plasmatiques des 17-hydroxycorticostéroides en liberté. Les échantillons de sang ont été prélevés le matin entre 8:15 et 8:45 heures, avant l'induction de l'anesthésie, durant l'anesthésie seule, durant l'opération et dans la salle de réveil. Le dosage des 17-OHCS libres dans le plasma a été fait par la méthode de Porter-Silber, modifiée par Peterson. Vingt malades ont reçu une anesthésie à l'halothane et onze autres malades n'ont reçu que la prémédication sans anesthésie.

Le niveau plasmatique moyen des 17-OHCS dans la période pré-anesthésique se tenait entre 10.0 et $10.8 \mathrm{mg}$. par 100 c.c., ce qui était sensiblement inférieur à ce qu'on trouve chez les non-prémédiqués. Bien que l'anesthésie à l'halothane durant 15 minutes après l'induction au pentothal n'ait produit qu'une augmentation sans importance du niveau des 17-OHCS, l'anesthésie à l'halothane durant 30 minutes (sans utiliser de pentothal) a sensiblement augmenté les niveaux plasmatiques des 17-OHCS au dessus des niveaux antérieurs à l'induction, de $10.8 \pm 1.4$ à $17.5 \pm 1.6 \mathrm{mg}$. par 100 c.c. Le stress chirurgical a augmenté de façon marquée les niveaux plasmatiques des $17-\mathrm{OHCS}$. Ces résultats indiquent que l'anesthésie à l'halothane a un effet stimulant sur la fonction du cortex surrénalien chez l'homme.

\section{REFERENCES}

1. Hammond, W. G.; Vandam, L. D.; Davis, J. M.; Carter, R. D.; Ball, R. M.; \& Moone, F. D. Studies in Surgical Endocrinology: IV. Anesthetic Agents as Stimuli to Change in Corticosteroids and Metabolism. Ann. Surg. 148: 199 (1958).

2. Virtue, R. W.; Helmrich, M. L.; \& Gainza, E. Adrenal Cortical Response to Surgery: I. The Effect of Anesthesia on Plasma 17-hydroxycorticosteroid Levels. Surgery. 41: 549 (1957).

3. Vandam, L. D. \& Moore, F. D. Adrenocortical Mechanisms Related to Anesthesia. Anesthesiology. 21:531 (1960).

4. Lewis, R. N. Plasma Hydrocortisone Concentrations in Relation to Anaesthesia and Surgery. Brit. J. Anaesth. 35: 84 (1963).

5. Silber, R. H. \& Porter, C. C. The Determination of 17, 21-dehydroxy-20-keto-steroids in Urine and Plasma. J. Biol. Chem. 210: 923 (1954).

6. Peterson, R. E.; Karrer, A.; \& Guerra, S. L. Evaluation of Silber-Porter Procedure for Determination of Plasma Hydrocortisone. Anal. Chem. 29: 144 (1957).

7. Siken, E. S.; Lipschitz, E. L.; \& KLEIN, R. The Effects of Preanesthetic Medications on the Blood Level of 17-hydroxycorticosteroids. Ann. Surg. 143: 88 (1956).

8. Han, Y. H. \& Brown, E. S. Pituitary Blockade by Meperidine in Man. Anesthesiology. 22; 909 (1961).

9. Migeon, C. J.; Tyler, F. H.; Mahoney, J. P.; Flonentin, A. A.; Castle, H.; Bliss, E. L.; \& SAMuELS, L. T. The Diurnal Variation of Plasma 17-hydroxycorticosteroids in Normal Subjects, Night Workers and Blind Subjects. J. Clin. Endocr. 16: 622 (1956).

10. Perkoff, G. T.; ErK-Nes, K.; Nugent, C. A.; Fred, H. L.; Nimer, R. A.; Rush, L.; Samuels, L. T.; \& Tyler, F. H. Studies of the Diurnal Variation of Plasma 17hydroxycorticosteroids in Man. J. Clin. Endocr. 19: 432 (1959). 
11. Franksson, C. \& Gemzell, C. A. Adrenocortical Activity in the Preoperative Period. J. Clin. Endocr. 15: 1069 (1955).

12. Stank, G. Der Einfluss der Narkose auf die Ausscheidung von Aldosteron, Cortison und Cortisol sowie Natrium und Kalium. Der Anaesthesist. 15: 1, 4 (1966).

13. HuME, D. M. \& BELL, C. C. Secretion of Epinephrine, Norepinephrine and Corticosteroid in Adrenal Venous Blood of the Human. Surg. Forum. 9: 6 (1959).

14. Oyama, T.; Saito, T.; Isomatsu, T.; Samejima, N.; Uemura, T.; \& Arimura, A. Plasma Levels of ACTH and Cortisol in Man during Diethyl Ether Anesthesia and Surgery. Anesthesiology. 29 (May, 1968).

15. Sandierg, A. A.; Enk-Nes, K.; Samuels, L. T.; \& Tyler, F. H. The Effects of 17hydroxycorticosteroids in Man. J. Clin. Invest. 33: 1509 (1964).

16. Murray, J. O. S.; Mark, L. J.; Colombo, F. V.; Josephs, B.; Leftin, J. H.; \& Leonaro, M. P. The Effect of Surgical Operation on the Plasma Clearance of Infused Cortisol. Ann. Surg. 148: 951 (1958).

17. Estep, H. L.; Litchfield, D. L.; Taylor, J. P.; \& Tucker, H. St. G., JR. Acute Effect of Traumatic Stress on Cortisol Metabolism in Man. J. Clin. Endocr. 26: 513 (1966). 